Journal of Education and Vocational Research

Vol. 4, No. 8, pp. 219-224, Aug 2013 (ISSN 2221-2590)

\title{
Vocational and Technical Education in Nigeria: Issues, Challenges and the Way Forward
}

\author{
Ubom, A.E.B, Haruna, O.I., ${ }^{*}$ Aregbesola, B.G. \\ University of Abuja, Nigeria \\ *busayo.aregbesola@gmail.com
}

\begin{abstract}
The paper seeks to look into the subject of vocational and technical education in Nigeria the issues involved, challenges encountered and how it can get better. The purpose is to unveil education as an instrument for transformation, productivity and motivator for the betterment of individual who has passed through it. In this paper vocational and technical education can be seen as that aspect of education use to gear the preparation of skilled manpower towards nation's development. Major constraints to vocational education such as nation's growth and vocational technical education, job scarcity and severance of Nigerian youths, implication of technology on vocational education training, parental attitudes toward vocational education, vocational for secondary schools, vocational technology elucidation for present needs and redundancy expiration \& engagement with vocational technical education were discussed. The paper concluded that Nigerians should give vocational technical education leverage in her educational system and some recommendations were proffered.
\end{abstract}

Key words: Technical, Vocational Education and Education

\section{Introduction}

Education all over the world has become an imperative possession if the generations that will understand the trend of all aspect of life that is, the political, economic, social, much more must emerge. Nigerians have historically considered VTE as an education program meant for low level, low brilliant and less privileged or second class citizens (Okoro, 1993; Eze \& Okorafor, 2012). In Africa, emergency of formal education has infiltrated the tradition/customary education of the so called 'The Blacks'. From $18^{\text {th }}$ century downward the popular professions here in Africa are: fishing, farming, joinery, sculpturing, carving, hunting, hair-dressing, etc. Chronicle of vocational education offers farming work to obtain food, build houses to obtain shelter, weave and produce clothes to wear against adverse weather- conditions; mankind also works to discover electricity, pipe-borne water, and many other modern conveniences (Nathaniel, 2002). Today reverse is the case both academically qualified and the less advantage learners prefer schooling at all cost because of the current norms of the day. It is amazing a situation which progressively decaying our specialty and capability is being embraced at all cost. Western education is not a course but a blessing to human kind; it helps in many ways that has kept substantial knowledge from generation-to-generation and be of immeasurable measure as development from one part of the world can be transferred to others via books, on-line, etc. But in the face of rapid technological advance, economic globalization and the intensification of competition both within developed and developing countries, it is now clear that human resources are the key to continuing prosperity in the advanced economies. It is also clear to most government, although to some perhaps more than the other that a maximum diffusion of education and training are necessary prerequisite for a healthy democracy and for maintaining a level of social cohesion and solidarity in fast changing and increasing pluralistic societies (Ruberti, 1993). Research has showed that an averaged child with a sound knowledge in art \&craft felt inferior to his/her counterpart who is a graduate. This syndrome has become the reason why our communities continue to produce half-baked graduate, who only sees in paper but cannot deliver when the practical aspect is being considered. Does this means that we have received education partially or what could the problem be? The growth of education up-till date is still questionable, is it a problem of a particular region, tribe, people or land. Teboho (2000) said that was our education mainly in size and not in quality? He further stated that the education system of Nigeria and some other development counties are still far from being ready for the challenges of preparing students for the contemporary global world. A case of Nigeria is an example, where every family wants to be proud of graduate at least but this has resulted to so many atrocities. 


\section{Nation's Growth and Vocational and Technical Education}

It has been observed that a nation's economic growth and the living standard of its people can be positively influenced by the quality and quantity of its human resources (Atsumbe, Emmanue, Igwe \& Atsumbe, 2012). It also supports what Enemali (2006) categorically said "Manpower is the basic resource; it is the indispensable means of converting other resources to mankind's use and benefit. This goes to prove that of nation's human resources can be improved through vocational and technical education. Vocational technical education is a crucial aspect of our education that remains silent, except for educationally less advantage student that cannot make-up their Senior Secondary School Certificate Examination, rather than being at home doing nothing, majority reluctantly considered the choice of technical education and at the end they do not considered of owning their private practice. It is sad to note that most of the students admitted into vocational and technical education programs are most of the times without requisite qualifications. The irrational practice of sending only drop-outs and mediocre students to technology base programs has been condemned by experts in vocational education (Atsumbe et al., 2012). Atsumbe (2010) observe that the vestiges of this obnoxious practice still persist up till date.

Job Scarcity and Severance of Nigerian Youths: Insight to developed countries shows that Vocational Education and Training has met great development as it is applied in great extend in order to equip their workforce with the new skills that the labor market demands (Mortaki, 2012).Job scarcity and unemployment has become common everywhere in Nigeria but the blame of this menace as always being thrown to the government not to the individual concern. Now should we look inward, is there no alternative for white collar job? Must our graduate continue to roam about the street? We must face this fact and stand-up for what is obtainable not to be chasing the shadow. So many researchers have written largely on vocational technical education (VTE), Lange and Topel (2001) a person with great skills will be able to increase employers or the workplace productivity. Cinterfor (2006) stated that VTE can be used as a tool to counteract at least in part, the harmful effect of unemployment by promoting greater job turnover and guarding against the risks of obsolescence.

Figure 1: A Model of Human Capital Theory

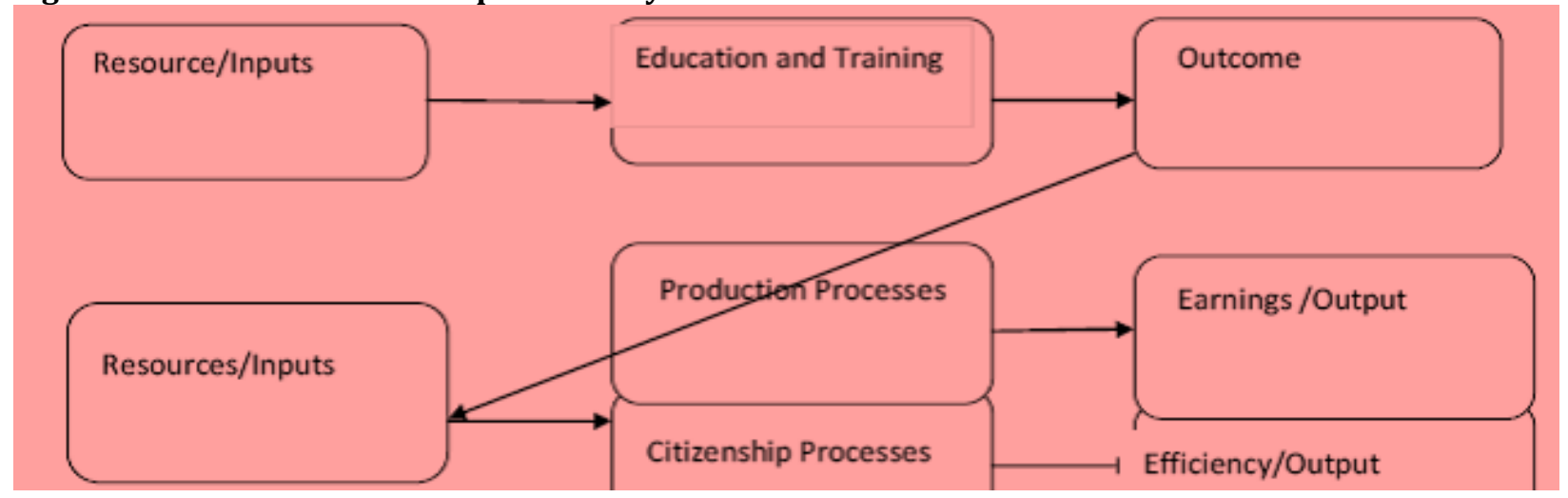

Source: Swanson\& Holton, (2001). Foundations of Human Resource Development. San Franciso: BerrettKoehler.

From fig. 1 above it can be seen that if the resource/input (training) is being infiltrated into our educational systems (VTE)this will resolve the problem of job scarcity and the engagement of youths in something productive and that can offer them earning which becomes the resultant or the outcome. From the figure also it can be observed that VTE cannot be over-emphasized in Nigeria as it paves way for application of scientific knowledge in providing solutions to practical problems that spate and riddle mankind. Its gives leverage to the human capacity to ensure that their needs and supply are been met through the production processes and citizen processes which most of the time come as a rewards of earning/efficiency output.

Implications of Technology on Vocational Education and Training: Arrival of technology has taken new order of the day here in Africa; Nigeria greeted this innovation with warm and tries to incorporate it into her 
different establishments. Education where the innovation is of core essential still crawl to appreciate it, and the hoary ways of doing thing still affect this old institution where knowledge is being disseminate. Thus, the backward in our mode of disseminating knowledge also might have contributed largely to the way the youngones perceive and comprehend what knowledge is all about. Bringing innovation to what we do will definitely affect the packing of our technical colleges and will grant the graduates a pledge of superiority as the graduate from other institutions. Actually, the re-packing of all our technical college is a crucial one if Nigerians and other Africans want to be delivered from the plight of unemployment. The pick of vocational training that is, polytechnic graduate still struggles with their major equipment and constant competition in labor markets with universities graduate. Modern and standard equipment should be in flux in our technical schools, refurbishing and renovation across developing countries should be of educational planners utmost. The case of lack of funds is now a normal situation generally in educational sectors of Nigeria may be in other developing countries and this has helped to depreciate the standard of our education, it should be noted that education will never flourish with adequate provision of funds. Ekpenyong (2005) said that education has being crippled by lack of funds and inadequate infrastructures. The standards of vocational colleges with essential infrastructure which will facilitate adequate practical that can give the students/learners of such colleges self-developed knowledge will give them confidence that push out the best in them. A case of the advent of electricity, cars, computer, modern furniture, construction and many more private companies who believed they can have written their names on the pillars of the hearts of many generations. Teaching with the sense of self-reliance should be part of the curriculum in our technical colleges which these learners go out to other parts of the world to see how things are being done.

Parental Attitudes towards Vocational Education: Self-importance in the hearts of parents as systematically confused their children in the choice of their careers, they believed that without western education no one respects you and you cannot get to the top of your career. Okocha (2009) stated that vocational education, which was designed to correct the lapses of the former system, is still boarded on ridicule, insolence because of society antipathy and parents avowed disapproval of discouragement of career training for their children in technical education. This situation continues to confuse these children/wards the more. Parents should understand that their wards have an inner inbuilt which propel and help them in whatever career they have chosen and they should not take advantage of these innocent minds to drive them to wrong profession. They should rather mentor their wards to choose the correct profession where they can flourish and even help to be employers of labor rather than be a nuisance on the streets.

Vocational Training for Secondary Schools: The $21^{\text {st }}$ century welcomes innovators, people who can think and create new things. The young minds have so many things which are mob-up. They seek for mentors who can help them to achieve it. Right from the secondary schools teachers sometimes are the first contacts that notice this trait in the student and most of the times they choose to encourage such student to a profession that will end with white-collar professions. A lot of innovations are out there waiting for someone to discover, and if we all end-up with office jobs how then do we discover new things. Aghenta (1985) said technical education is concerned contends with training that borders on acquisition of knowledge and skills in woodworks metalwork, electrical/electronics, welding and fabrication, building, auto-mechanics etc. And when students are being show the technical know how they breed on it to develop new things. What we enjoy today all over the world is not the product of paper work alone, but creative thinking to bring out those things that make our lives comfortable. Ranging from our domestic used, house appliances, and many other things as people think the world becomes a better place and idleness will be destroyed.

Secondary schools should be seen as a platform where students will be motivated to develop curiosity to create new things, thus create an interest in technical colleges. The jet-club and many other extra-curricular activities at secondary school levels should help to exhibit the young talent where people can volunteer to sponsor their work. The changing of education systems in Nigeria from the 6-5-4 to 6-3-3-4 presently now to,9-3-4 should really portrait and pronounce with sincerity the inculcation of vocational education. Many countries across the globe have experienced viable technical education and the result has gradually brings turn-around positive outcome. For instance, Denmark has made efforts through her government to increase the number of training places and strengthening their practical element this reform implies substantial changes in structure and content such as emphasis on social and personal skills. Michael (2002); Khan \& Ghouri ( 2012), In Germany, one of their educational objectives is to promote the vocational education of 
gifted young people and to raise the standard of vocational education and training (Michael, 2002). Also, in Kenya, the 8-4-4 system was introduced with emphasis on technical and vocational education which ensured that the graduate students at every level have some scientific and practical knowledge that can be utilized for self-employments, salaried employment or further training (Republic of Kenya, 1984).

\section{Vocational Technology Education and Elucidation for Present Needs}

Pictures of former education needs urgent clarification in Africa (Nigeria is not left out), former education which is meant to develop people minds on how to go about thing so as to achieve the best in what they do is now seeing as the only way out to do thing. Primary focus of education is to divulge individual's mind on how to see things different with critical order of thinking. It roles in individual's life helps to shaping whatever is being conceive in chronological order where architectural beauty of such thing will be exposed. Today, both the urban and rural dwellers see no sense in engaging in other form of occupation if not office work, the ratio of 1:100 vacancies gets increasing every day. Natural resources waste away down here in Africa, no man want to cultivate the land, fishing is now obsolete thing to do, so many resources: like good trees for sculpturing are there in the forest where people rather use them for cooking instead of making fortune. In Nigeria, the wealth of the nation is being shifted to crude oil; no one cares to remember the '70s agricultural boom. Pudding (1994) defined vocational-technical education as that type of education which fits the individual for gainful employment in recognized occupation as semi-skilled workers or technicians or sub-professionals. Also the advent of mechanization will even profile accepting environment not only for the semi-skilled workers also for graduate at various levels that can make good use of the education they have acquire to create jobs. Countries like China and India dweller majorly on other forms of occupation like extensive mechanized farming which has boomed their economy. For example, medicinal products which have resulted to the production of different food supplements have created jobs for many graduates here in Africa.

In Nigeria, these products are been corporately hawk even in office. These are good example of what an individual with a right mind set can do with his/her educational qualification. All around the world the set of people topping the chart of the richest never come from civil servant because their take home cannot even cater for their daily necessities. In all educators across all levels of education should develop the mind of an individual to see things the way they are, not to chase the shadow. Education is to set of us free from slavery and not to curb our ideas up with token being received at the end of the month. Vocational education should be given a good leverage in our society since we are blessed with so many resources that can help to eradicate poverty. Adeyemi (1997) depicted vocational education as that aspect of the total education process that focuses on individual occupation, while Olaitan, (1994) explained vocational education as that type of education which is considered with the development of skills, knowledge and attitudes necessary for success to any occupation. Thus, education should be used to strengthen our skills and not to limit us, as we look forward to incorporate our country to 2020 vision across the globe.

Redundancy Expiration \& Engagement with Vocational Technical Education: When the right thing is being done the people move forward, vice-visa. The rate of poverty gets increase every day, it is amazing that people doze off when alertness is highly needed. Many graduates are out there seeking for whom to employ them and the slogan of joblessness is now a cool music for those desires to dance it. Vocational education will both equipped an individual with the knowledge of former education and the knowledge of self-reliance. Rather in Nigeria our youth flux the labor market to seek for white collar job, in which they are supposed to be employer of labor. From genesis of white collar jobs where we are, majority of our youth loitering on the street jobless and no one knows the revelation of the white collar saga. Presently, it an established around the globe, that averagely we are experiencing massive unemployment not only in Africa but also in developed countries. Even an average individual's find it difficult to sponsor standard education for their wards, government intervention and other external aids have been of great help towards financing education. Vocational education puts leverages on the honor being awarded from the institution as the career seem to have the technical know-how that can helps in other way round in any establishment. Vices across the globe can be majorly traced to idleness than any other factors, as majorities of the victims are youth who are jobless. The world today should be able to provide substantial solution to this problem which has raged across the globe from human-trafficking to prostitution, child abuse, and the current one terrorism. 


\section{Conclusion}

Vocational education has been seen as a light of the present need in Africa, especially Nigeria with her numerous mineral resources. The need to embrace this form of education cannot be negotiable, as government alone does not a room to accommodate thousands of graduates who comes out of schools now and then. The country has to wake-up from her slumber to fortified vocational technical schools and also provide creation for more rather than giving birth to graduates they will not capable to provide for. Teachers and parents are to encourage these young-ones and not to disabuse their mind towards their chosen careers.

\section{Recommendations}

- Vocational education should be given due priority in our educational systems as it is designed in all the curricula especially technical education also graduates of such institution should be financially supported by subsidizing various equipment needed to be self-employed after graduation.

- Government, corporate bodies, philanthropists, NGOs, individual should see to the provision of modern equipment in all our vocational schools.

- Employers should stop the madness of certificate segregation in labor market as this will discourage students to attend vocational institution and go for acquisition of university degrees.

- Establishment of vocational technical schools should be encouraged among private individuals, government and NGOs, as the present ratio is 1 technical school to 40 regular schools. In fact, most of the states in Nigeria hardly possess up to 3 technical colleges.

- Adequate funds should be released for the smooth running of our vocational technical schools as practical remains the back-bone of knowledge acquired in such schools. Nigerian Government should allocate $26 \%$ of its annual budget to education as it is suggested by UNESCO.

- Career talks(seminars, workshop, exhibitions and competition)should be frequently organized for learner's right from primary schools and parents should be discouraged in forcing their profession on their children/wards.

\section{References}

Adeyemi, A. A. (1997). Role of Women in Vocational Education for Economic Development. Bichi Journal of Education, 1(2), 73-75.

Aghenta, J. A. (1985). Analysis of Education and Employment of Vocational and Technical Schools Graduates Human Resources. Development Approach in Ehiametalor and Adesina (Ed), Trend in Vocational Education in Nigeria. Benin Education Research Association, pp. 54-71.

Atsumbe, B. N., Emmanuel, R., Igwe, C. O. \& Atsumbe, J. (2012). Repositioning Vocational and Technical Education for Effective Manpower Production in Nigeria. IOSR Journal of Mechanical and Civil Engineering (IOSRJMCE), 1(4), 01-06.

Atsumbe, B. N. (2010). Technology Education a Veritable Tool for Poverty Alleviation. A Paper Presented at the 1st Faculty of Science National Conference of University of Abuja. FCT.18th - 20th January.

Cinterfor, I. (2006). Vocational Training and Employment Promotion. Cinterfor: Inter American Research and Documentation Centre in Vocational Training.

Ekpenyong, L. E. (2005). Foundations of Technical and Vocational Education. Evolution and Practice. Benin: Ambik Press Limited.

Enemali, J. D. (2006). Strategies for Effective Management of technical colleges in Northern Nigeria. Spectrum Journal, 2(2), 13 -19.

Eze, T. I. \& Okorafor, O. A. (2012).Trends in Technical, Vocational Education and Training for Improving the Nigerian Workforce. Ebonyi Vocational and Technology Education Journal, 1(1), 107-115.

Khan, N. R. \& Ghouri, A. M. (2012). Human Resource Practices and Supply Chain Management in Pakistan: Empirical Findings from Small and Medium Sized Firms. Germany: LAP LAMBERT Academic Publishing.

Lange, F. \& Topel, R. (2001). The Social Value of Education and Human Capital. Retrieved from http://www.econ.yale.edu/ f188/Handbook Chapter.pdf

Michael, A. (2002). Development in the Field of Vocational Education \& Training (VET) System of Brussels. Member States. European Center for the Development of Vocational Training. 
Mortaki, S. (2012). The Contribution of Vocational Education and Training in the Preservation and Diffusion of Cultural Heritage in Greece: The Case of the Specialty Guardian of Museums and Archaeological Sites. International Journal of Humanities and Social Science, 2(24) 51.

Nathaniel, T. (2002). Science and Technology in the Development of Agriculture in Daily Sketch 21-02-02.

Olitan, S. 0. (1994). Domestication of the Technical Teacher Training Program \& Its Implications for Sustainable Economic Development. Journal of Technical Teachers education, 1(2), 10-14.

Okocha, M. (2009). Parental Attitudes towards Vocational Education. Implications for Counseling. Edo Journal of Counseling. Delta Steel Company Technical High School, Ovwian Aladja, Delta State, 2(1).

Okoro, O. M. (1993). Principles and Methods in Vocational and Technical Education. Nsukka University Trust Publication.

Pudding, L. C. (1994). Youth \& vocational Technical Education in Nigeria. Studies in Technical Teachers Education (STTED). Journal of Federal College of Education, 1, 56-60.

Republic of Kenya, (1984). Ministry of Education, Science and Technology: 8-4-4 System of Education. Nairobi: Government Printer.

Ruberti, M. (1993). Guidelines for Community Action in the Field of Education and training, European Commission Working Paper, Unpublished.

Swanson, R. A. \& Holton, E. F. (2001). Foundations of Human Resource Development, San Francisco: BerrettKoehler.

Teboho, M. (2000). Nigeria Education Sector Analysis: An Analytical Synthesis of Performance and Main Issues. New Youth University: New York, NY. 